\title{
THE ROLE PLAYED BY RECRUITMENT AGENCIES IN THE EMIGRATION OF SOUTH AFRICAN NURSES
}

\author{
Mrs MJ Oosthuizen \\ MA Cur \\ Lecturer, Department of Health Studies, University of South Africa \\ Corresponding author: oosthmj@unisa.ac.za
}

\section{Dr VJ Ehlers}

D Litt et Phil

Senior Lecturer, Department of Health Studies, University of South Africa

\section{Prof K Jooste \\ D Litt et Phil \\ Associate Professor, School of Nursing Science, University of Johannesburg}

Keywords: emigration of South African nurses; expatriate South African nurses; international recruitment of nurses; recruitment agencies

\begin{abstract}
Active recruitment of foreign nurses might offer solutions to many countries' nursing shortages. During 1999, the International Council of Nurses (ICN) expressed concerns regarding the aggressive international recruitment of nurses. The ICN maintained that internationally recruited nurses might be particularly at risk of exploitation or abuse. The ICN denounced unethical recruitment practices that might exploit nurses (ICN, 1999a:1-6). Many nurses who leave the Republic of South Africa might use recruitment agencies' assistance. These concerns raised by the ICN indicated the need for obtaining information about the emigration of South African nurses and the role played by recruitment agencies. The purpose of this study was to explore and describe how recruitment agencies contributed to the emigration of South African nurses. Both qualitative and quantitative approaches were used. A purposive sample of recruitment agencies that recruited South African nurses to practise in foreign countries $(N=4)$ was drawn. The second sample, a purposive sample selected through snowball sampling consisted of South African registered nurses who were practising in foreign countries $(N=27)$. The findings obtained from structured interviews conducted with recruitment agencies were supported by findings from e-mail responses from nurses working in foreign countries. These research results indicated that recruitment agencies in South Africa provided professional services to nurses who wanted to work in foreign countries. Contrary to research reports published in other countries, no evidence was found of nurses being exploited by recruitment agencies in South Africa.
\end{abstract}

\section{OPSOMMING}

Die aktiewe werwing van buitelandse verpleegkundiges kan oplossings bied vir baie lande se tekorte aan verpleegkundiges. Die Internasionale Verpleegstersraad (IVR) het in 1999 sy kommer uitgespreek oor die aggressiewe internasionale werwing van verpleegkundiges en beweer dat verpleegkundiges, wat internasionaal gewerf is, 'n besondere risiko loop om uitgebuit te word. Die IVR het onetiese werwingspraktyke wat verpleegkundiges uitbuit veroordeel (ICN, 1999a:1-6). Talle verpleegkundiges wat die Republiek van Suid-Afrika verlaat, maak gebruik van werwingsagentskappe. Die kommer wat deur die IVR uitgespreek is, het die noodsaaklikheid uitgewys om inligting oor die emigrasie van Suid-Afrikaanse verpleegkundiges, en die rol van werwingsagentskappe in hierdie land, in te win. Die doel van die studie was om die bydrae van werwingsagentskappe in die emigrasie van Suid-Afrikaanse verpleegkundiges te ondersoek en te beskryf. Beide kwalitatitiewe en kwantitatiewe benaderings is gevolg. ' $n$ Doelbewuste steekproef van werwingsagentskappe wat Suid-Afrikaanse verpleegkundiges gewerf het om in die 
buiteland te praktiseer $(\mathrm{N}=4)$ is getrek. Die tweede steekproef, ' $n$ doelbewuste steekproef deur sneeubalsteekproefneming verkry, het bestaan uit Suid-Afrikaanse verpleegkundiges wat in die buiteland praktiseer het ( $N=27$ ). Daar is bevind dat werwingsagentskappe in Suid-Afrika professionele dienste lewer aan verpleegkundiges wat in die buiteland wil gaan werk. In teenstelling met verslae wat in ander lande gepubliseer is en wat impliseer dat werwingsagentskappe verpleegkundiges uitbuit, is sodanige bewyse nie in Suid-Afrika gevind nie.

\section{INTRODUCTION}

The emigration of professional nurses from the Republic of South Africa (RSA) has aroused considerable interest from the nursing profession, health care institutions and the South African government. The decision to emigrate is a personal one, depending largely on individual circumstances. Many nurses who leave the RSA might use recruitment agencies' assistance. During 1999 the International Council of Nurses (ICN) expressed concern regarding the aggressive international recruitment of nurses, sometimes taking advantage of uninformed nurses. The ICN maintained that private recruitment efforts focus on large numbers of recruits, sometimes depleting a given health facility or contracting a significant number of newly graduated nurses from a country. The contents of the contracts offered to these nurses were neither monitored nor regulated and nurses might be employed under false pretenses or misled about the conditions of employment. Internationally recruited nurses might be particularly at risk of exploitation or abuse because of the difficulty in verifying the terms of employment due to the distance, language barriers and costs involved (ICN, 1999a:1-6). These concerns raised by the ICN indicated the need for obtaining information about the emigration of SA nurses and the role played by recruitment agencies in this country.

Active recruitment of foreign-educated nurses might offer solutions to many countries' nursing shortages. Buchan, Parkin and Sochalski (2003:8) pointed out that international recruitment has increasingly become a solution to the nursing shortages in some countries. McQuaid Dvorak and Waymack (1991:120) maintained that "in all countries, nurses constitute one of the most important health care delivery resources and therefore officials of other national governments view recruitment of their nurses as a drain on their own supply of a scarce national resource". In its position statement the ICN (1999a:1-6) denounced unethical recruitment practices that exploit nurses and called for a regulated recruit- ment process based on ethical principles that guide informed decision-making and reinforce sound employment policies on the part of governments, employers and nurses.

According to Buchan (2001b:20) the practice of recruiting nurses abroad would continue to generate controversy. He pointed out that "...countries such as South Africa, which can ill afford to lose scarce nursing skills, have seen some of their best and brightest nurses leave for the United Kingdom (UK) and other countries such as Ireland and New Zealand". Buchan argued that although international mobility of nurses was nothing new, the UK's involvement in international recruitment reflected its failure to educate, recruit and retain sufficient UK nurses. Despite criticism, the UK Department of Health indicated that international recruitment would be part of their solution of nursing shortages. During the first few months of 2000 a total of 7383 initial nurse entrants were admitted to the UK from overseas countries, particularly from South Africa, Australia and the Philippines.

The ICN's (1999b:1) position statement Nurse Retention, Transfer and Migration recognised the right of individual nurses to migrate while acknowledging the possible adverse effect that international migration might have on health care quality. According to Buchan (2001a:67), England became the first country to attempt to build ethics into its international recruitment practice when the UK Department of Health issued its guidelines on international recruitment of nurses in 1999. At the Royal College of Nurses' (RCN) Congress in 2001 nurses deplored the systematic depletion of other countries' nursing workforce to address UK shortages (O'Dowd \& Akid, 2001:4). Despite the UK Department of Health's guidelines on international recruitment, during 2002 the UK government revealed that, two-thirds of the agencies that supply nurses to National Health Systems (NHS) trusts do not comply with ethical recruitment practices (Mulholland, 2002:3). It was revealed that more than a third of foreign nurses had to pay fees 
of up to 2000 UK pounds to their employers or recruitment agencies prior to being able to work in the UK. According to the RCN secretary, Beverly Malone, it was not acceptable that nurses paid commission to recruitment agencies to work in the UK. It was further alleged that RCN Nurseline, a confidential advice and information service for nurses and midwives, was aware of more than 1000 instances of foreign nurses being exploited during the preceding 18 months (Anon., 2002:11). In some cases nurses were requested to pay hundreds of pounds for information which was available free of charge from the Internet. Cases of exploitation varied but included nurses arriving in the UK to find their contracts' terms and conditions changed, nurses working for less than 9000 UK pounds per year, poor housing and accommodation and foreign nurses who were employed on terms and conditions different from those of their UK counterparts (War, 2002:11; Williams, $2001 ; 15)$. Philip Hufton, lead facilitator for the Federation of Independent Nursing Agencies admitted that there were unscrupulous agencies charging large sums of money. He "regretted such behaviour" and added that he thought it was "absolutely scandalous" (Parish, 2000:13).

In a study on international nurse mobility funded by the WHO, Buchan et al. (2003:48) noted the role of recruitment agencies as stimulators or active intermediaries in the process of international nurse recruitment. These authors found that recruitment agencies were of different types (international, single country focusing on assisting outflow, single country focusing on assisting inflow) and also functioning in different ways. In some cases the agency was the instigator of the movement of the nurse; in others, it fulfilled a facilitative or supporting role. These authors asserted that there were reports in some countries that some agencies exploited nurses, by providing misleading information about pay and conditions in destination countries, or by charging high fees for nurses to move from one country to another.

\section{RESEARCH PROBLEM}

Unknown numbers of South African nurses emigrate annually, presumably using the services of recruitment agencies. Although allegations were made, especially in the UK, that some recruitment agencies operated in questionable ways in recruiting foreign nurses to work in foreign countries, no similar South African study could be traced. Thus the role played by recruitment agencies in the emigration of South African nurses appeared to be unknown and needed to be explored and described.

\section{PURPOSE OF THE STUDY}

The purpose of this study was to explore and describe the role played by recruitment agencies in the emigration of South African nurses, as described by these agencies in the RSA and by South African nurses working in foreign countries.

\section{DEFINITION OF CONCEPTS}

Emigration: Leaving one country to settle in another (Sykes, 1976:338). In this study it referred to South African nurses leaving the RSA to practise in foreign countries.

Foreign country: Refers to any country, other than South Africa, that employs South African nurses to practise nursing in that country.

Recruitment agency: Agency that recruits South African nurses to work in foreign countries.

South African nurse: In the context of this study a South African nurse is an educated person who is registered with the South African Nursing Council and is legally authorised to practise nursing as set out by the Nursing Act, no 50 of 1978, as amended.

\section{RESEARCH METHOD}

Triangulation of data and methods were used. Triangulation refers mainly to the use of multiple methods of data collection with a view to increasing the reliability of observation. In their discussion on triangulation Babbie and Mouton (2001:275) stated that by combining methods in the same study, researchers could partially overcome the deficiencies that flow from one method. The use of multiple methods allowed the data yielded by interviewing recruitment agents to be crosschecked and validated against the data yielded from narratives by South African nurses working in foreign countries. This gave a more comprehensive picture of the role played by recruitment agencies in affecting the emigration of South African nurses, portraying the information received from recruitment agencies and from nurses who had emigrated. The research methods will 
be described separately for the two phases of the research.

\section{Phase One}

In this phase, a quantitative approach was used to obtain information about recruitment agencies.

\section{Population and sample}

The first target population comprised recruitment agencies that advertised their services in newspapers and nursing journals in South Africa during 2003. Time and cost considerations influenced the decision to use a sample of the recruitment agencies and not the entire population of recruitment agencies operating in South Africa. Non-probability sampling was used to select recruitment agencies for interviewing because no complete list of all agencies engaged in recruiting South African nurses to work overseas could be accessed. A purposive sample of recruitment agencies based on the following characteristics was drawn:

- recruitment agencies that advertised their services in newspapers and nursing journals in South Africa

- recruitment agencies that recruited South African registered nurses to work in any foreign country.

According to Lobiondo-Wood and Haber (1994:294) purposive sampling might be appropriate for the collection of exploratory data from a highly specific population, particularly when the total target population was unknown to the researcher. This statement was applicable to this target population. The limitations imposed on this study by using purposive sampling implied that the data obtained from the recruitment agencies would only be applicable to the participating agencies and might not be generalisable to all the recruitment agencies operating in the RSA.

Agencies recruiting South African registered nurses to work in foreign countries were selected. Only four recruitment agencies were willing to be interviewed, on condition that questions regarding the numbers of South African nurses who had been recruited to work in foreign countries would not be asked. Unfortunately not one of the agencies that advertised jobs in the United States of America (USA) was willing to be interviewed. Two informal information sessions, advertised in daily newspapers and presented by nurse recruitment agencies in South Africa, were also attended to gain some insight into the information supplied during such sessions.

\section{Data collection and analysis}

Despite the amount of literature available on the emigration of nurses, literature on the management of recruitment agencies was extremely limited. Since these agencies are involved in the daily recruitment and assistance of emigrating nurses they were considered experts in the field and therefore their inputs were considered to be valuable. The interview schedule consisted of questions that provided information on the countries for which the agencies recruited; profiles of the nurses who were recruited; strategies used by agencies; costs incurred by emigrating nurses using services of recruitment agencies; and benefits for nurses leaving the RSA. Both open and closed-ended questions were included in the schedule. Responses to open-ended questions were categorised into appropriate classifications through the process of content analysis (Polit \& Hungler, 1999:209) and discussed. The interviews were conducted by one interviewer, the principal investigator in this study.

Due to the small number of recruitment agencies being willing to participate in this study, no pretest could be carried out. Thus the reliability and validity of the research results might have been compromised to some extent. However, the questions were discussed with nurse researchers and with a statistician who agreed that the questions were relevant to the role played by recruitment agencies in recruiting South African nurses to work in foreign countries.

\section{Ethical considerations}

The ethical considerations pertinent to conducting this research implied the participants' right to privacy including their right to refuse to participate in this research, their right to refuse to be interviewed, their right to anonymity and confidentiality and their right to informed consent. These rights were protected and adhered to in the following ways: The names of recruitment agencies that were interviewed would not be mentioned in any report or publication of the research results, neither would any data be linked to any specific recruitment agency. The recruitment agents were informed about the purpose of the research and the agents 
who were not willing to be interviewed were not pressurised in any way. Their right to refuse to participate in the research was respected.

\section{Phase Two}

A qualitative approach was used in phase two of the study to analyse data obtained from South African nurses working in foreign countries. These nurses were asked to comment on the services delivered by recruitment agencies operating in South Africa.

\section{Population and sample}

The second population consisted of South African registered nurses who were working in foreign countries during the data collection phase (1 October to $31 \mathrm{De}-$ cember 2003). The second sample consisted of South African registered nurses who had left South Africa to practise in foreign countries. A purposive sample selected through snowball sampling was used. According to Henning (2004:71) there is one common denominator in purposive and snowball sampling, namely, "the people most suitable to wander with on the research journey are selected at the time that they are needed". Although this approach did not provide a representative sample (Burns \& Grove, 1999:238) it provided access to some nurses working in foreign countries. The researcher attempted to select participants who would be able to provide extensive information (Burns \& Grove, 2003:255) about their decisions to emigrate and their experiences in dealing with recruitment agencies. Since there were no formal registers or lists with the names of South African nurses working in foreign countries, snowball sampling had to be used to identify participants. According to De Vos, Strydom, Fouche and Delport (2002:336) snowball sampling is valuable in qualitative research since it is directed at individuals that are difficult to identify. A total of 27 narratives were analysed. The decision to stop searching for more participants was made when no new information or themes emerged in the analysis (Burns \& Grove, 2003:374).

\section{Data collection and analysis}

In the qualitative phase data were collected by requesting South African registered nurses working in foreign countries via e-mail to write their stories in response to the following set questions:

- Did you make use of the services of a recruitment agency?
- How did you experience the services of the agency with which you signed up?

- How much did you pay for the agency's services?

\section{Credibility and trustworthiness}

In order to enhance the credibility of the research (Tjale \& De Villiers, 2004:242) data were collected from two different categories of participants, namely representatives of recruitment agencies and South African nurses working in foreign countries.

The process of data verification was carried out according to Guba's model of trustworthiness as described in Krefting (1991:215-216). No further steps to ensure trustworthiness could be adopted as the e-mails or written narratives were submitted anonymously and the names had been removed prior to data analysis - as promised to the participants in the letter requesting their participation.

\section{Ethical considerations}

Although the e-mail addresses were known of the participating South African nurses working in foreign countries, these were erased prior to the commencement of the data analysis. Only the principal investigator had access to the names and e-mail addresses of the participants. Neither their names, nor e-mail addresses, nor any personal identification data would be disclosed at any stage of the research to any person or institution. The research report would present only the data analysed from all the responses combined, without identifying any specific individual participant.

\section{RESEARCH FINDINGS}

The research results will be presented separately for the two phases of the research and thereafter these results will be compared and contrasted.

\section{Research results: Phase 1: Recruitment agencies}

Since no references to recruitment agencies operating in South Africa could be found in the literature search, it was impossible to support the findings of this study by literature references. The four agencies that were interviewed were competitors in the recruitment market, yet the information and answers provided by them 
were very similar, sometimes identical, in their responses to many of the questions.

The four interviewed recruitment agencies indicated that they recruited South African nurses for various countries and that they had contracts with specific hospitals in those countries. One recruitment agency only recruited for hospitals in the UK and the Middle East, while the other three agencies recruited for hospitals in the Middle East (Saudi Arabia and the United Arab Emirates), the UK, Australia and New Zealand. The interviewed agencies did not recruit nurses for the USA or Canada. All four agencies mentioned that active recruitment of South African nurses for positions in NHS hospitals in the UK was postponed after a request by the British authorities that recruitment agencies should not target developing countries to combat the nursing shortage in the UK. The ban on recruitment of South African nurses was apparently requested by South African authorities and introduced by UK authorities. This followed a request by former President Nelson Mandela in 1999, that the recruitment of South African nurses to work in the UK should be banned. At that stage South Africa was the UK's second most popular country from which nurses were recruited. Apparently this ban was only applicable to hospitals belonging to the National Health System (NHS), or government hospitals (Anon., 2000:13). The interviewed agencies referred to this as a Code of Conduct or a moratorium. However, three agencies confirmed that although they respected the Code of Conduct and did not actively recruit nurses for the UK, they received numerous requests from South African nurses who wanted to work in the UK and those nurses were offered jobs in the UK. They also received requests from South African nurses working in the Middle East who wished to relocate to the UK. One agency stated that although they did not recruit nurses for the UK's NHS for the past two years due to the Code of Conduct, they had a contract with a private hospital group in the UK for which they were recruiting South African nurses.

Items were included to identify the speciality areas in high demand and to determine the level of experience of nurses who left South Africa. All four agencies indicated that nurses with specific skills in critical care and operating theatre were in high demand in all the countries that needed South African nurses, but that nurses with any other South African qualifications could be placed. One agency specified that there is a huge demand in the UK for psychiatric nurses. According to all the agents, foreign countries required some degree of nursing experience. Two to three years' experience seemed to be the average requirement. All four agencies agreed that degree and diploma qualified nurses were in demand in foreign countries, but according to one agency representative "... a degree is a feather in your cap when you are looking for a job in a foreign country".

None of the recruitment agencies targeted nurses of a specific age. It was, however, mentioned that nurses younger than twenty-five years of age would not receive a visum to work in Saudi Arabia. According to the interviewed representatives there was no age limit to apply for a job in a foreign country. One agency indicated that they did not recruit nurses older than fiftytwo while another one mentioned that they would accept applications from nurses up to the age of fifty-five years.

All the agencies offered a comprehensive service to applicants who wanted to work in foreign countries. They offered assistance with professional nursing registrations and with obtaining work permits or visums in all the foreign countries for which they recruited. The agencies confirmed that they would assist applicants with relocation by booking air tickets and accommodation.

All agencies offered applicants contracts with specific hospitals in the different countries. They also provided successful applicants with support or acculturation programmes while still in South Africa. The information provided by agencies included written guidelines as well as one on one information sessions to nurses leaving for Saudi Arabia. They emphasised that it was very important for nurses to understand the cultural differences and restrictions before they left the RSA. They provided compact discs and printed matter on the country to which applicants would be going. They also showed videos and provided information in groups as well as on individual basis to prospective and successful applicants. All four agencies provided in-depth information on the cultural differences that candidates might experience when they work in foreign countries.

In Saudi Arabia, candidates had to write a pharmacol- 
ogy test upon arrival and hereafter a buddy was appointed to assist the candidate for three months. The agencies did not prepare candidates for this test in South Africa, but candidates received the necessary support when they arrived in Saudi Arabia.

Agents explained that agencies did not offer free flights to successful applicants. This was a fringe benefit offered by the employers in the foreign countries, especially employers in the Middle East. They always offered free flights to the Middle East as well as free flights back to South Africa once the contract expired. Applicants also received free flight tickets for vacation every six months. Employers in the UK also offered free one way flights to successful candidates in some instances, but not always. Some hospitals assisted with airfare or free flights but nurses were either expected to pay back the amount as soon as they started earning a salary in the foreign country or to work for a specified period of time for the hospital concerned. Nurses leaving for Australia and New Zealand had to pay for their flights.

The information provided by the agents indicated that the leave policies in the different countries were more or less similar ranging from six to seven weeks per annum. The only country that offered South African nurses tax-free salaries and free accommodation was Saudi Arabia. In some instances nurses who left for hospitals in the UK might get subsidised accommodation. Employers would, however, arrange accommodation for nurses who needed it. Nurses in all countries enjoyed free basic medical assistance. Employers in all countries offered orientation programmes for foreign nurses joining their staff. Social activities in foreign countries were arranged by one of the agencies while in Saudi Arabia nurses were offered tours and other social activities by the employing hospitals.

It also seemed as if South African nurses had many opportunities to further their qualifications. Representatives indicated that South African nurses in the UK, Australia and New Zealand could apply to do specific courses after they had worked in these countries for a predetermined period of time. In Saudi Arabia there were no opportunities to obtain additional qualifications. However, in-service training was provided continuously in this country.

All the agencies indicated that nurses' salaries were quoted in the relevant countries' foreign currencies or in USA dollar, not in South African Rand. The strength of the South African currency therefore significantly influenced the nurses' earnings in South African Rand. In the period during 2001 - 2003 when the South African currency was under pressure and weak against the other currencies, expatriate nurses earned much higher salaries when converted to SA Rand than they did during the latter half of 2003 and 2004 when the SA Rand was stronger against the US dollar. Although the salaries did not change, the stronger Rand had a negative effect on the nurses' earnings when converted into SA Rand. South African nurses in foreign countries reportedly earned the following average salaries:

Middle East: 2200 - 2750 US\$ per month tax free (in May 2004 this amounted to a R16 000 - R18 000 tax free salary per month)

United Kingdom: 22000 - 28000 Pound per annum (in May 2004 this amounted to a salary of R286 000 R364 000 per annum or R23 000 - R30 000 per month before tax)

Australia: In South African currency nurses earned approximately R16 000 - R18 000 per month (before $\operatorname{tax})$

New Zealand: In South African currency nurses earned approximately R14 000 per month (before tax)

Nurses were employed on the same terms and conditions as nurses/citizens of the specific country and the same benefits such as paid leave and sick leave were included in their packages. The agents considered the salaries and benefits offered to South African nurses in the Middle East to be very generous. Accommodation was provided free of charge and the salaries were tax free. This implied that nurses only had to pay for their meals. Nurses in Saudi Arabia had to work between 40-46 hours per week. Salaries and benefits in the UK, New Zealand and Australia were fair and according to the interviewed agents, South African nurses were able to afford an above average lifestyle in all these countries.

All four the agencies advertised their services in South African nursing journals because they believed this would give them the widest exposure. The agencies did not use daily newspapers for regular advertisements. They advertised in Sunday newspapers or daily newspapers only when they had special assignments or wanted to advertise specific positions. They also used 
Internet facilities to provide information about the hospitals and countries for which they recruited. Interested nurses could contact them via the Internet.

No interviewed agency charged nurses any fees for services rendered. The agencies were paid by the recruiting hospitals in the foreign countries. Expenses incurred by nurses leaving the country differed according to specific countries, but the following expenses were listed in response to open-ended questions;

- Nurses leaving for Saudi Arabia needed almost no financial contribution of their own to enable them to leave. They had to pay for their own medical examination which was done in South Africa and which could cost up to R2000, as well as a police clearance certificate. Costs for photocopies of their documents and passport photos would also be paid by the applicant.

- Nurses leaving for the UK incurred costs, but in certain instances, hospitals refunded the nurses after they had worked for a specified period of time. Applicants were responsible for the Nursing and Midwifery Council (NMC) registration and SANC verification fees as well as the cost of a NMC pack. The client in the UK paid for the work permit. Sometimes candidates had to pay their own airfare, but single tickets might be included in the benefits offered by respective recruiting hospitals.

- When Australia was the country of choice nurses had to have at least R15000 on standby to be able to pay for their airfare, accommodation, SANC verification and SANC transcripts.

\section{Research results: Phase 2: South African nurses working in foreign countries}

The data were derived from the narratives of 27 South African nurses working in foreign countries. Individuals were selected to participate based on their first hand experience (Streubert \& Carpenter, 1999:22) with the services rendered by recruitment agents and the application for jobs in foreign countries. Eight of the participants either did not use the services of a recruitment agency or did not comment on their services.

Data analysis commenced as soon as the first narratives were received from South African nurses working in foreign countries. The narratives were received as email printouts or in written format for those participants who preferred to do it this way. At first the submitted narratives were read and reread until the researcher became familiar with the content. Thereafter segments of meaning units (implying a segment of the text which is meaningful by itself) were identified. Thereafter specific topics were identified from the narratives. The identified topics were written in the margin of each document. A list was then compiled of all topics, in columns. The topics were compared and similar topics were underlined in specific coloured pens. Similar topics were then clustered and names that captured the underlying ideas were given to the clusters. Major topics, unique topics and miscellaneous topics were then grouped into columns. In this way Tesch's (1990) methodology was used to analyse the South African nurses working in foreign countries' written descriptions of their experiences in dealing with recruitment agencies. The researcher as well as an independent coder coded the narratives. After completion of the process of coding, organising into subcategories and categories the researcher identified specific themes. Data saturation was reached after 15 narratives had been analysed. However, the researcher continued to analyse all 27 narratives received from South African nurses working in foreign countries. The addition of the information received after saturation was reached confirmed the findings in the first 15 narratives. It did not add any new information.

Three themes related to recruitment agencies were derived from the narratives received from the South African nurses. These themes related to the quality of services rendered by the recruitment agencies that functioned in South Africa, support and preparation offered by recruitment agencies to applicants and the financial contribution that applicants had to make to enable them to leave the RSA. The themes that emerged in the qualitative analysis of the narratives provided data that supported the findings obtained during the structured interviews with recruitment agents.

\section{Triangulation of findings: structured inter- views conducted with recruitment agents and narratives from South African nurses working in foreign countries}

The themes that emerged in this phase of the research 
will be discussed individually.

\section{Theme 1: Quality of services rendered by the recruitment agencies that operate in South Africa}

The majority of the participants described the quality of service rendered by recruitment agencies operating in South Africa to be very good or excellent. A few comments, however, indicated that some participants were not completely satisfied with the services rendered by the recruitment agencies that they used.

Category 1: Positive experiences regarding the quality of service rendered by recruitment agencies

Participants explained that they experienced the attitudes of and services rendered by recruitment agencies to be positive and supportive. Most participants used only one word to describe the services of the specific recruitment agencies namely, "excellent".

The words of one participant reflected many participants' feelings and experiences: "I used a recruitment agency. Their services were excellent".

The majority of participants felt that recruitment agencies provided an efficient and fast service as this comment suggests: "... they were fast in processing my application".

Category 2: Negative experiences regarding the quality of service rendered by recruitment agencies

Some participants commented that their expectations with regard to a recruitment agency were unmet. Four participants made negative comments on the time it took to get a job offer in a foreign country and the amount of paperwork involved in processing the application. The following quotes illustrate the finding: "I did work through two agencies. The first one took very long finding something suitable and therefore I consulted another agency that was a lot more efficient". "My experience with the agency was satisfactory. Most people would like faster progress...".

Literature on the time it took South African nurses to relocate to foreign countries or the amount of paperwork involved in a foreign job application could not be found, nor checked with recruitment agencies because these aspects depended on the individual applicant and the specific country's requirements.

\section{Theme 2: Support and preparation of- fered to applicants}

Although the majority of participants commented positively on the support received from the agencies, there were a few negative comments regarding the lack of preparation on working in specific foreign countries or the support that applicants received once they had left South Africa.

Category 1: Positive experiences regarding the support and preparation of applicants

Participants explained that they were supported and received regular feedback on the processing of their applications as the following quotes demonstrate: "They were really friendly and took time to answer all my questions". "They tried to provide us with as much info as possible which was good enough for me". Literature that supported this finding could not be found.

Category 2: Negative experiences regarding the support and preparation of applicants

Only two participants in this study mentioned negative experiences and felt exploited. However, references to exploitation of foreign nurses were found in the literature. Pearce (2002:14-15) alleged that cases of exploitation varied but that some internationally recruited nurses working in the UK were paid less than the national minimum wage and the pay received while they are doing adaptation courses was too low. The following comments illustrated this: "Although the South African agency was good throughout the whole process when recruiting, they deliberately did not furnish us with all the details, and we found ourselves stranded in a foreign country. To be honest we felt like we have been dumped to nowhere". "I was told that I will be assessed for three months, thereafter I will be graded according to my experiences. That meant working and paid like somebody straight from school but taking on more responsibility which was not recognised financially. The assessment was not done after a year ... I felt betrayed and let down".

\section{Theme 3: Financial contribution}

None of the participants were charged any fees by recruitment agencies for their services, neither were they expected to contribute towards the airfare. The only 
expenses that some of the participants mentioned were related to medical examinations, photocopies of documents and NMC registration fees. Some participants also referred to the pocket money that they needed to survive in the UK, until they received their first month's salary. The following quotations confirm the finding: "The agency did not charge me anything for the service rendered". "... they even paid my airfare" (UK participant). "I made use of an agency ... at no costs, though I paid my Council fees" (UK participant).

At the RCN Congress in 2002 it was revealed that more than a third of foreign nurses had to pay fees of up to 2000 UK pounds to their employer or recruitment agency before being able to work in the UK and that thousands of foreign nurses were exploited in some way (Anon., 2002:11). No support for these allegations was found in this study. The findings from the structured interviews at recruitment agencies were supported by the findings in the narratives received from South African nurses, who used the services of recruitment agencies to obtain jobs in foreign countries. None of the interviewed recruitment agencies charged applicants any fees for their services. None of the participants had to pay money to recruitment agencies or employers. This was confirmed by participating nurses who were working in foreign countries.

The findings in this study indicated that the majority of participants that commented on the services of recruitment agencies in South Africa were very satisfied with the services rendered by these agencies. They commended the supportive and caring way in which they were treated throughout the process of application for jobs in foreign countries and their successful appointments to positions in foreign countries. The findings suggested that recruitment agencies provided nurses who contacted them with sufficient information to make informed decisions.

Two informal information sessions hosted by international recruitment agencies that operate in South Africa were attended. None of these agencies were interviewed by the researcher. The information given at these sessions supported the findings of the structured interviews with the four agencies, as well as the experiences of South African nurses working in foreign countries.

\section{LIMITATIONS OF THE RESEARCH}

Only the recruitment agencies willing to grant interviews participated in this research. Consequently, the research results might not be generalisable to all recruitment agencies in South Africa. No participating agency recruited nurses for the USA, thus the research results might not be applicable to agencies recruiting South African nurses to work in the USA.

No census of South Africans working in foreign countries could be accessed. This necessitated the utilisation of snowball sampling techniques. This approach limits the generalisability of the research results as not all South African nurses working in foreign countries might have similar perceptions about recruitment agencies.

\section{RECOMMENDATIONS}

Future researchers could use questionnaires (rather than interviews) to be completed anonymously to all agencies recruiting South African nurses to work in foreign countries. Gaining the co-operation of these agencies to assess their own services, as judged by South African nurses working in foreign countries, could contribute towards obtaining more data from more agencies and from more nurses. Country specific information from both the agencies and the South African nurses working in foreign countries, could help the agencies to provide more effective services and the South African nurses to adapt more effectively to working and living in foreign countries.

Recruitment agencies might be expected to render services to nurses wishing to return to South Africa, and this aspect should be addressed by future researchers to identify ways and means in which nurses' return to South Africa's professionally active nursing ranks could be facilitated.

\section{CONCLUSION}

The findings of the structured interviews conducted at recruitment agencies and the qualitative analysis of data obtained from South African nurses' narratives, indicated that recruitment agencies in South Africa provided a service to nurses who wanted to work in foreign countries in a professional and supportive way. Contrary to 
reports suggesting that some recruitment agencies were exploiting nurses, especially in the UK, no such evidence was found in this study. Recruitment agents were reportedly honest in recruiting South African nurses, did not charge any fees for their services and did not exploit their clients. The findings suggested that the role played by recruitment agencies in South Africa in the emigration of South African nurses is one of facilitator rather than instigator of the movement of nurses from the RSA. It seems possible that, in future, recruitment agencies might also have a role to play in facilitating South African nurses' return to this country. This aspect deserves further investigations focusing on both the recruitment agencies' and on the South African nurses' potential needs and capabilities.

\section{LIST OF REFERENCES}

ANON. 2000: South African nurses banned from working in the United Kingdom. Nursing Update, 24(2/3):13.

ANON. 2002: War on foreign nurse abuse. Nursing Times, 98(18):11.

BABBIE, E \& MOUTON, J 2001: The practice of social research. Cape Town: Oxford.

BUCHAN, J 2001a: Nurses moving across borders: "Brain drain" or freedom of movement? International Nursing Review, 48(1):65-67.

BUCHAN, J 2001b: The way we were. Nursing Standard, 15(4):20-21.

BUCHAN, J; PARKIN, T \& SOCHALSKI, J 2003: International nurse mobility. Trends and policy implications. Geneva: World Health Organization.

BURNS, N \& GROVE, SK 1999: Understanding nursing research; $2^{\text {nd }}$ edition. Philadelphia: WB Saunders.

BURNS, N \& GROVE, SK 2003: Understanding nursing research; $3^{\text {rd }}$ edition. Philadelphia: WB Saunders.

DE VOS, AS; STRYDOM, H; FOUCHE, CB \& DELPORT, CSL 2002:

Research at grass roots for the social sciences and human service professions; $2^{\text {nd }}$ edition. Pretoria: Van Schaik.

ICN see International Council of Nurses.

HENNING, E 2004: Finding your way in qualitative research. Pretoria: Van Schaik.

INTERNATIONAL COUNCIL OF NURSES 1999a: Ethical nurse recruitment. Position statement. Geneva: ICN. Retrieved from http:/ /www.icn.ch/psrecruit01.htm on 17/05/2002.

INTERNATIONAL COUNCIL OF NURSES 1999b: Nurse retention, transfer and migration. Position statement. Geneva: ICN. Retrieved from http://www.icn.ch/psretention.htm on 17/05/2002 KREFTING, L 1991: Rigor in qualitative research: The assessment of trustworthiness. American Journal of Occupational Therapy, 45(3):214-222.

LOBIONDO-WOOD, G \& HABER, J 1994: Nursing research. Methods, critical appraisal, and utilization; $3^{\text {rd }}$ edition. St Louis: CV Mosby. MCQUAID DVORAK, E \& WAYMACK, MH 1991: Is it ethical to recruit foreign nurses? Nursing Outlook, 39(3):120-123.

MULHOLLAND, H 2002: Agencies failing to recruit ethically despite government guidelines. Nursing Times, 98(46):3.

O'DOWD, A \& AKID, M 2001: Delegates deplore foreign hiring. Nursing Times, 97(21):4-5.

PARISH, C 2000: Broken promises. Nursing Standard, 15(3):13. PEARCE, L 2002: World of difference. Nursing Standard, 16(32):14-15.

POLIT, DF \& HUNGLER, BP 1999: Nursing research. Principles and methods; 6th edition. Philadelphia: JB Lippincott.

STREUBERT, HJ \& CARPENTER, DR 1999: Qualitative research in nursing. Advancing the humanistic imperative; $2^{\text {nd }}$ edition. Philadelphia: JB Lippincott.

SYKES, JB 1976: The concise Oxford dictionary of current English; 6th edition. New York: Oxford University Press.

TESCH, R 1990: Qualitative research. Analysis types and software tools. New York: Falmer.

TJALE, AA \& DE VILLIERS, L 2004: Cultural issues in health and health care: A resource book for Southern Africa. Kenwyn: Juta. WILLIAMS, R 2001: Welcome to nurse here. Nursing Standard, 15(44):15-16. 